\title{
SACRECTOMY WITH ILIO-LUMBAR STABILIZATION DUE TO LOW-GRADE CHONDROSARCOMA OF SACRUM AND ILIAC WING. CASE REPORT OF THE FIRST SURGERY PERFORMED IN THE REPUBLIC OF NORTH MACEDONIA
}

\author{
Ilir Hasani ${ }^{1}$, Danica Popovska ${ }^{2}$, Rezeart Dalipi ${ }^{2}$, Teodora Todorova ${ }^{2}$, \\ Qemal Rushiti ${ }^{3}$, Nikola Gramatnikovski ${ }^{4}$, Arzana Hasani Jusufi ${ }^{5}$ \\ ${ }^{1}$ University Clinic for Traumatology - Skopje, Republic of North Macedonia \\ ${ }^{2}$ University Clinic for Orthopedic Diseases - Skopje, Republic of North Macedonia \\ ${ }^{3}$ University Clinic for Digestive Surgery - Skopje, Republic of North Macedonia \\ ${ }^{4}$ University Clinic for Thoracic and Vascular Surgery - Skopje, Republic of North Macedonia \\ ${ }^{5}$ University Clinic for Gastroenterohepatology - Skopje, Republic of North Macedonia
}

Corresponding author: Ilir Hasani, University Clinic for Traumatology - Skopje, Republic of North Macedonia, e-mail: ilirku@yahoo.com

\section{ABSTRACT}

Low - grade chondrosarcomas are primary malignant bone tumors that are resistant to chemo- and radiotherapy and are treated surgically. Sacral localization makes surgical resection technically difficult due to position, anatomic structures involved, and large tumor size at detection. The risk of complications is high. We present the introduction of a novel surgical technique in our country, sacrectomy with ilio-lumbar stabilization. This was performed on a 67-year-old man with low-grade chondrosarcoma of the sacrum with sacroiliac joint involvement. The procedure was performed via an antero-posterior approach in two stages. Ilio-lumbar fixation with a mesh cage bridge was used to obtain spinopelvic continuity and stability. Sacrectomy is a technically demanding procedure that requires careful preoperative planning and a multidisciplinary approach, as well as high level of surgical experience.

Keywords: chondrosarcoma, sacrectomy, ilio-lumbar stabilization

\section{INTRODUCTION}

Chondrosarcoma is a primary malignant bone tumor or, in some cases, secondary due to the malignant transformation of enchondroma or osteochondroma. Approximately $5 \%$ of the tumors are located in the sacrum, with typical localization eccentrically in the upper portion, which can lead to sacroiliac joint involvement. [1-4] Generally, patients present with pain in the affected area. Neurological symptoms may be mixed and they can vary from radicular pain which is registered in $24 \%$ of the patients to muscle weakness. $[2,5]$

Appropriate staging of the tumor is essential for prognosis and adequate choice of surgical treatment. Low-grade lesions are frequent in the pelvis and have an eccentric, lobular appearance and dense spicules of calcification, as in our case. [6] Surgery is the treatment of choice for chondrosarcomas, because they do not respond to chemotherapy or radiotherapy. [7] 
In this report we present a radical surgical procedure, sacrectomy with ilio-lumbar stabilization for treatment of low-grade chondrosarcoma of the sacrum and iliac wing. This procedure was performed for the first time in our clinic and in our country.

\section{CASE REPORT}

We present a case of a 67-year-old patient, admitted to the University Clinic for Traumatolo- gy with intense pain in the left gluteal region for a few months. Upon clinical examination, there was palpable painful tenderness in the left gluteal region. Left peroneus nerve palsy and a positive Lasegue sign at 20 degrees were detected. The imaging studies including: X-rays, CT scans with angiography, MRI (Figure 1.) and a Tc 99m bone scan showed a soft tissue mass with a $12 \mathrm{~cm}$ diameter which destroys the sacrum, involving left sacral foramina, spreading laterally to the left sacroiliac joint and anteriorly in the pelvis and receiving vascularization mainly from the internal iliac artery. The soft tissue mass is in close

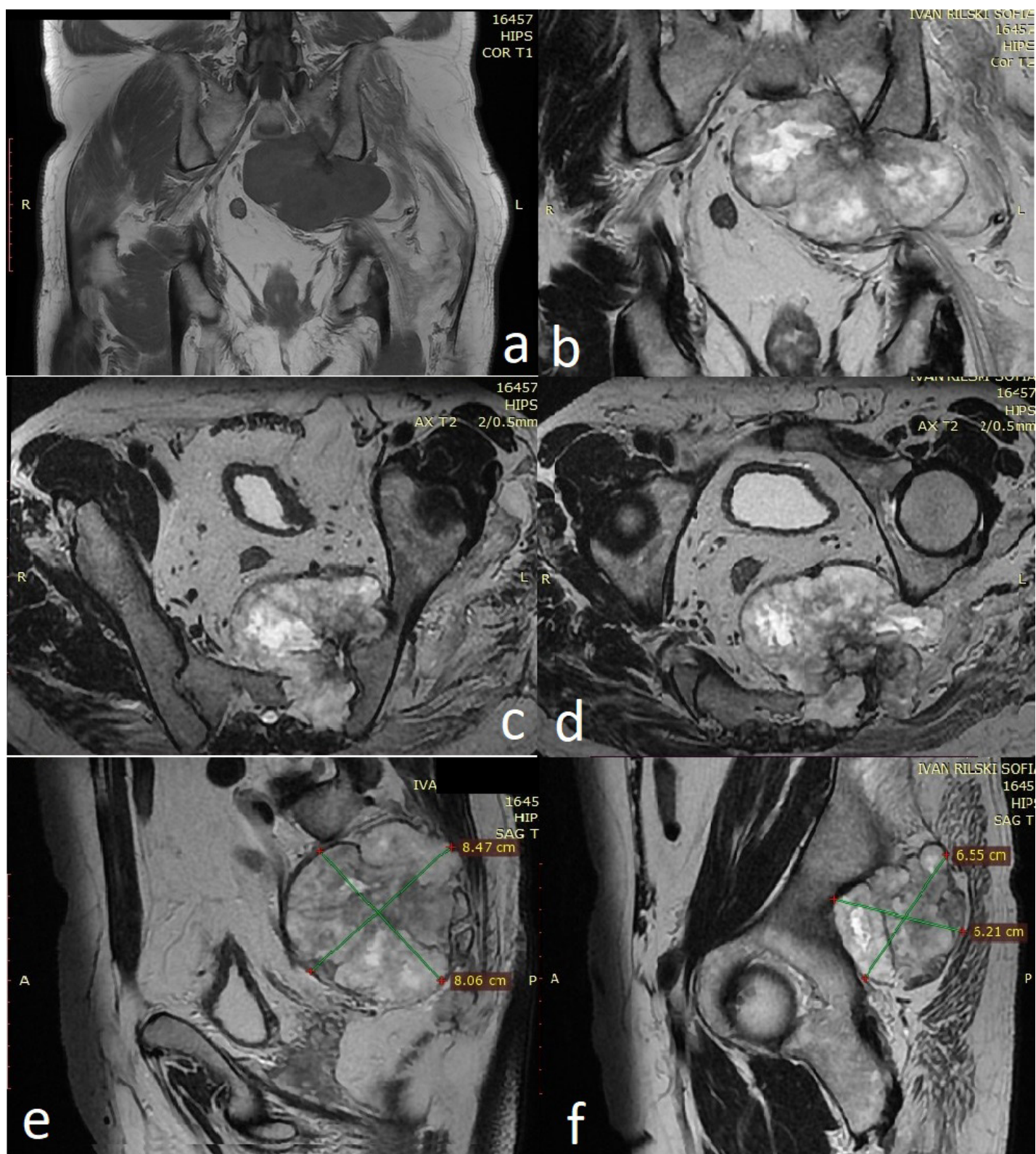

Figure 1. Preoperative MRI: a. coronal T1 image of tumor b. coronal T2 image of tumor. Sciatic nerve entrapment is visible. $c, d$. transversal T2 images showing sacrum and sacroiliac joint destruction and expansion of tumor in the pelvis and left gluteal region. e, $f$ : sagittal T2 slices depicting tumor dimensions and relationship with iliac wing posteriorly. 
contact but does not invade the left ureter. Posteriorly, the mass displaces, but does not invade, gluteal muscles and it is in close contact with the iliac wing, creating satellite nodules. No distant metastases were detected with the imaging studies. CT guided puncture biopsy showed lowgrade chondrosarcoma. All necessary investigations and preoperative preparation were completed within a one month timeframe and thereafter, surgery was performed.

A combined antero-posterior approach was chosen, and resection of the tumor was performed as a two-stage procedure.

A midline transperitoneal approach was used for the dissection of the anterior tumor. The retroperitoneum was exposed and the rectum was mobilized. The left internal iliac artery and vein were ligated, as well as the median sacral artery, therefore embolization was not needed. The tumor margin was explored and released from all anteriorly adhering soft tissue. The L5-S1 disc was exposed and removed. Osteotomy was performed through the sacral foramina on the right side, while taking care to preserve the sacral nerve roots and the lumbosacral plexus. On the left side, due to tumor invasion of the SI joint, osteotomy was performed through the iliac wing, connecting the middle of the iliac crest with the middle of the greater sciatic notch.

In the second stage, the tumor was approached via a posterior incision extending mid- line from L3 to the coccyx and from the lowest point extending inferiorly and laterally towards the left greater trochanter. Thus, spinal structures including facet joints and transverse processes, both iliac crests, bilateral sacral foramina, left sciatic nerve, and posterior aspect of left hip joint were exposed. The sacral canal was dissected and L5 and all left sacral nerve roots were divided, while the dural sac and right nerve roots were preserved. The left sciatic nerve was divided because it was entrapped in the tumor. A portion of the gluteus maximus muscle, the gemelli and piriformis were sacrificed. Osteotomy was completed through sacral foramina on the right side and through the iliac wing on the left side. Final tumor mobilization and resection was completed by osteotomy of the left ischial spine, thus releasing the sacrospinous ligament and division of the sacrotuberous ligament. The tumor specimen was removed en-bloc with neighboring healthy bone, without tumor fragmentation and to macroscopically healthy margins.

Spinopelvic reconstruction was performed during the second stage. On the left side, a double rod construct with side-to-side connectors connecting L3-L5 pedicle screws with iliac and ischial tuberosity screws was used. On the right side, a single rod construct connecting L3 and L5 pedicle screws and an iliac screw was used. A cross-connecting rod was used to fix both sides together. A mesh cage filled with bone graft was used to bridge the gap between the remaining

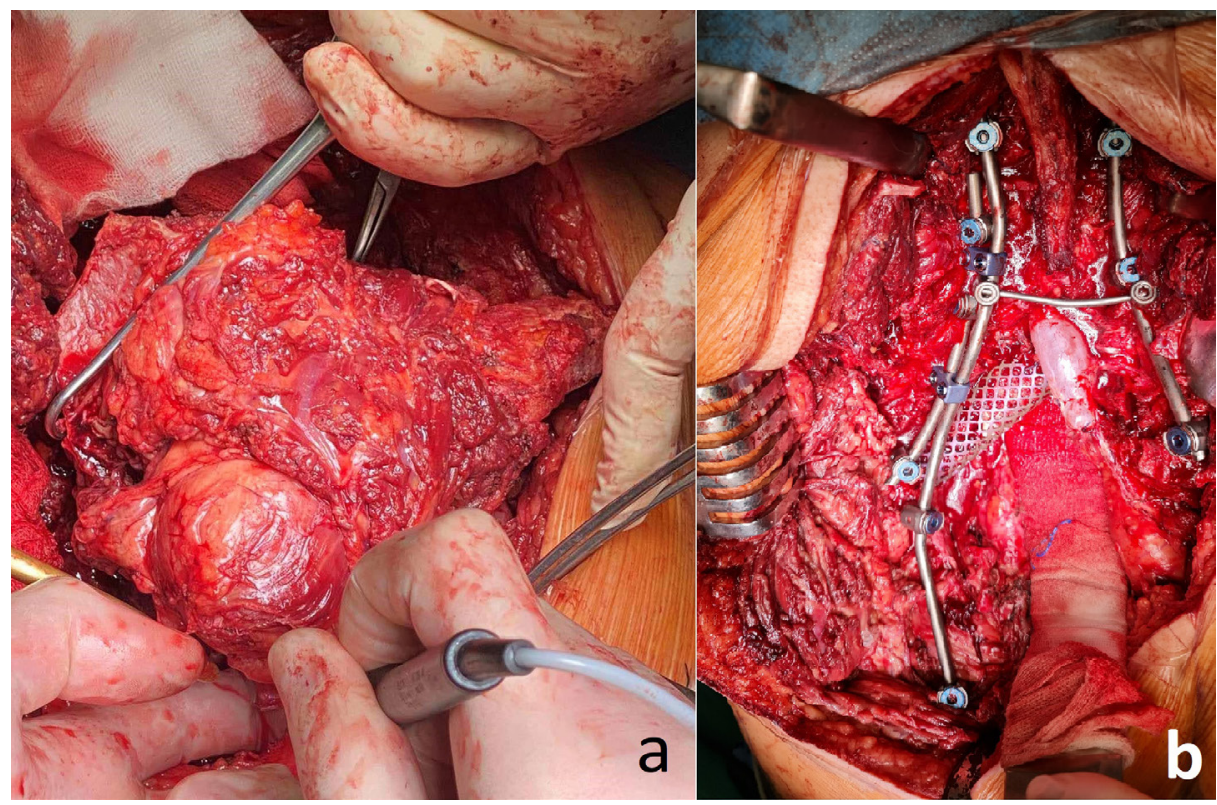

Figure 2. Surgical procedure. a. final tumor mobilization before removal. $B$. tumor is removed and fixation materials are in situ. Dural sac is exposed. 


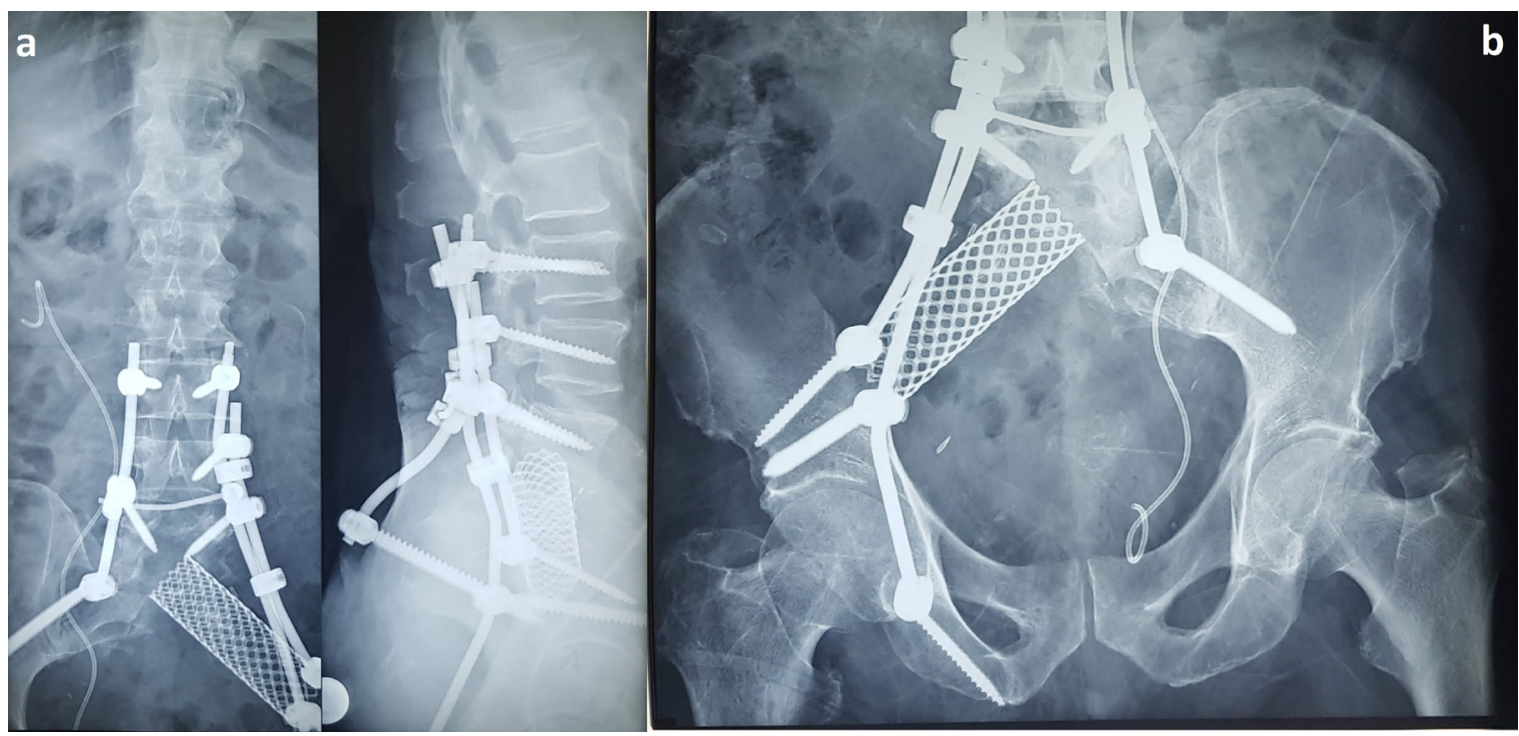

Figure 3. Postoperative X-rays. $a$. AP and lateral view of lumbosacral spine. B. AP view of pelvis.
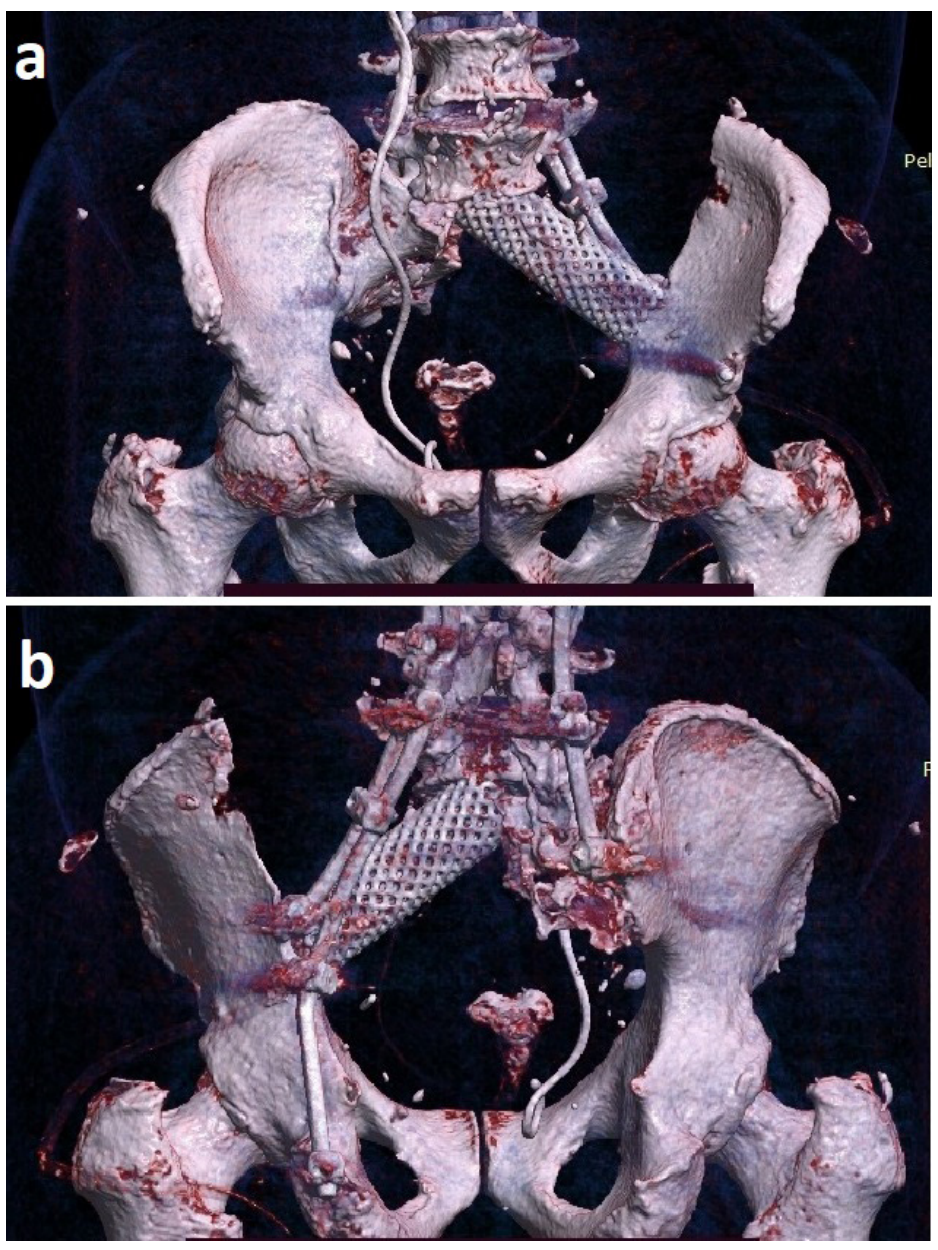

Figure 4. Postoperative CT of pelvis $-3 D$ reconstruction. $a$. anterior view $b$. posterior view. 
right sacral wing and the iliac wing. (Figures 2, $3,4)$ A polypropylene mesh was used to reinforce the posterior wall and prevent abdominal content herniation. Suction drains were placed and the wound was closed primarily.

The patient received a $2100 \mathrm{ml}$ blood transfusion during and after the first stage of surgery and $2100 \mathrm{~mL}$ during posterior surgery, for a total of $4200 \mathrm{~mL}$ during the entire hospital stay.

Pathohistological analysis showed that the tumor tissue was composed of a dominant chondroid matrix containing hypocellular but also richer cell regions composed of chondrocytes located in lacunae. Chondrocytes were slightly pleomorphic, with numerous binucleated chondrocytes, while mitotic activity was not found. The finding was representative of low-grade chondrosarcoma (pTNM $($ UICC-8) $=p T 3 b, p N x$, low grade, stadium IB), with negative margins and observing the two main principles for tumor radicality and sterility.

Postoperatively, there was seroma formation and superinfection with P. aeruginosa and Enterococcus, which was resolved with antibiotic treatment and the wound healed primarily. The patient was verticalized with crutches. Upon discharge, there was fecal incontinence.

On the last follow up of the patient, 5 months postoperatively, the patient was disease free, the postoperative scar was normal, and there was fecal incontinence. The patient refused a colostomy. He is capable of ambulation with single crutch support.

\section{DISCUSSION}

Total sacrectomy is a technically demanding procedure associated with multiple complications, whose benefit is in better disease-free survival times compared to less invasive procedures for malignant sacral tumor resection. [8]

Achieving adequate margins when resecting tumors which involve the sacrum is extremely difficult, because at the time of detection they are large in size and, in $26 \%-56 \%$ of the cases, tumors invade the sacroiliac joints. [9-12] Adequate en-bloc resection, such as in the case presented, lowers the local recurrence rate and improves survival. A study by Bergh et al. showed a 25-fold increased risk of local recurrence when surgical margins were intralesional as opposed to wide. In their series of 55 surgically treated conventional chondrosarcomas, the development of local recurrence was significantly associated with an increased risk of tumor-related death, but it did not increase risk of metastasis. According to several studies, the adequacy of the definitive surgical procedure is in accordance to histologic grading, the most important prognostic factor in conventional chondrosarcoma and the only treatment factor that potentially could be controlled or modified. Therefore, any type of extensive surgery aimed at adequate tumor resection should be favored. [13, 14]

Alternative treatment methods, such as radiofrequency ablation have been shown to be successful for small central lesions, but these are not applicable for large sarcomas such as in this case. Curettage and cryosurgery is effective when performed on low grade chondrosarcoma in long bones, but recurrence is high when used for bones of the axial skeleton. [15] The Enneking classification system is essential for planning the surgery and defining the needed borders for resection. Local recurrence is a problem in these type of tumors, and second surgeries are rarely successful.

A multidisciplinary approach is necessary in the process of diagnosing and treatment of these patients, and in this case it included: trauma surgeons, orthopedic surgeons, oncologists, abdominal surgeons, gastroenterohepatologist, radiologists, urologists and a vascular surgeon. Adjuvant treatment with embolization may be effective to lower blood loss and help prevent a neurologic deficit by controlling the tumor size in certain types of tumors, such as giant cell tumors, but this has little effect in low grade chondrosarcoma with low vascularization and is rarely used in these cases. In our case, the tumor received almost all vascularization from the internal iliac artery, and its ligation prevented all blood loss due to tumor neoangiogenesis. Blood loss was associated only with an extensive surgical approach and was controlled by meticulous hemostasis and systemic tranexamic acid application.

Most authors recommend a combined antero-posterior approach for high and total sacrectomies, with the anterior approach being used for mobilizing the tumor and posterior for definitive removal and reconstruction, as in our case. $[4,16]$ According to Clarke et al, posterior-only sacral resection can have an acceptable outcome, as long as the tumor does not invade the lumbosacral junction or viscera. [17] 
Sacrificing spinal nerves during surgery can lead to significant neurologic deficit, including ambulatory difficulty, sphincter and sexual dysfunction, but unilateral nerve root division causes only motor disfunction and no, or limited, sphincter control deficit. [18] In this case, left L5 and left sacral roots had to be sacrificed and right roots were preserved, resulting in the need for support of ambulation. Considering the possibility of sphincter function with the remaining sacral nerves, we did not decide on a colostomy during the first surgery. Our patient was incontinent by the time he was discharged and we expected that he may regain partial sphincter control. Colostomy is considered an option if there is no recovery.

Spinopelvic reconstruction for addressing instability and providing adequate support for every day movements is another problem in sacrectomy. Some authors omit reconstruction based on the rationale that hardware predisposes infection and without it the lumbar spine migrates inferiorly between the ilia and remains stable. [19] We consider the reconstruction necessary for early stability and mobilization, although bony union is necessary for definitive stability. There are different types of constructs used and most authors propose iliolumbar stabilization, interconnecting rods, two iliac screws, and bone grafts to bridge the gap. [20] We used a double rod construction and an additional ischial screw to add stability to this type of fixation.

Radical en-bloc resection improves the clinical results of the surgery, but it does not go without complications. Major complications reported are: vascular injuries to the main blood vessels, myocardial infarction, embolism, infections, transitional renal failure and ureteral injury, paraplegia, cerebral hematoma (due to cerebrospinal fluid leak), and wound healing complications. In addition to neural injury, morbidity may occur due to the disruption of weightbearing joints. [19-21]

\section{CONCLUSION}

Sacrectomy is a technically demanding procedure that requires careful preoperative planning and a multidisciplinary approach, as well as a high level of experience, in order to optimize surgery time, minimize complications and obtain adequate tumor removal. Its variants are the method of choice for treatment of low-grade sacral malig- nancies, which have a limited response to other types of oncologic treatments. Adequate surgical resection is the most important prognostic factor for sacral chondrosarcoma outcome.

\section{REFERENCES}

1. Giuffrida AY, Burgueno JE, Koniaris LG, Gutierrez JC, Duncan R, Scully SP. Chondrosarcoma in the United States (1973 to 2003): An analysis of 2890 cases from the SEER database. J Bone Jt Surg - Ser A. 2009;91(5):1063-1072. doi:10.2106/JBJS.H.00416

2. Boriani S, De Lure F, Bandiera S, et al. Chondrosarcoma of the mobile spine: Report on 22 cases. Spine (Phila Pa 1976). 2000;25(7):804-812. doi:10.1097/00007632-200004010-00008

3. Gitelis S, Bertoni F, Picci P CM. Chondrosarcoma of bone. The experience at the Istituto Ortopedico Rizzoli. J Bone Jt Surg Am. 1981;63(8):12481257.

4. Fourney DR, Rhines LD, Hentschel SJ, et al. En bloc resection of primary sacral tumors: classification of surgical approaches and outcome. J Neurosurg Spine. 2005;3(2):111-122. doi:10.3171/spi.2005.3.2.0111

5. York JE, Berk RH, Fuller GN, et al. Chondrosarcoma of the spine: 1954 to 1997. J Neurosurg. 1999;90(1 SUPPL.):73-78. doi:10.3171/ spi.1999.90.1.0073

6. Marco RA, Gitelis S, Brebach GT, Healey JH. Cartilage tumors: evaluation and treatment. J Am Acad Orthop Surg. 2000;8(5):292-304. doi:10.5435/00124635-200009000-00003

7. Van Maldegem AM, Gelderblom H, Palmerini E, et al. Outcome of advanced, unresectable conventional central chondrosarcoma. Cancer. 2014;120(20):3159-3164. doi:10.1002/ cncr.28845

8. Hulen CA, Temple HT, Fox WP, Sama AA, Green BA, Eismont FT. Oncologic and functional outcome following sacrectomy for sacral chordoma. J Bone Jt Surg - Ser A. 2006;88(7):1532-1539. doi:10.2106/JBJS.D.02533

9. Li D, Guo W, Tang X, et al. Preservation of the contralateral sacral nerves during hemisacrectomy for sacral malignancies. Eur Spine J. 2014;23(9):1933-1939. doi:10.1007/s00586013-3136-3

10. Ozaki T, Rödl R, Gosheger G, et al. Sacral infiltration in pelvic sarcomas: Joint infiltration analysis II. Clin Orthop Relat Res. 2003;(407):152158. doi:10.1097/00003086-200302000-00023

11. Court C, Bosca L, Cesne A Le, Nordin JY, Missenard G. Surgical excision of bone sarcomas 
involving the sacroiliac joint. Clin Orthop Relat Res. 2006;451(451):189-194. doi:10.1097/01. blo.0000229279.58947.91

12. Kawai A, Healey JH, Boland PJ, Lin PP, Huvos AG, Meyers PA. Prognostic factors for patients with sarcomas of the pelvic bones. Cancer. 1998;82(5):851-859. doi:10.1002/ (SICI) 1097-0142(19980301)82:5<851::AIDCNCR8>3.0.CO;2-M

13. Bergh P, Gunterberg B, Meis-Kindblom JM, Kindblom LG. Prognostic factors and outcome of pelvic, sacral, and spinal chondrosarcomas: A center-based study of 69 cases. Cancer. 2001;91(7):1201-1212.

14. A P, MG A, M S, et al. Decision making in primary sacral tumors. Spine J. 2009;9(5):396-403. doi:10.1016/J.SPINEE.2008.10.001

15. Mohler DG, Chiu R, McCall DA, Avedian RS. Curettage and Cryosurgery for Low-grade Cartilage Tumors Is Associated with Low Recurrence and High Function. Clin Orthop Relat Res. 2010;468(10):2765. doi:10.1007/S11999-010$1445-\mathrm{Y}$

16. Zhang HY, Thongtrangan I, Balabhadra RSV, Murovic JA, Kim DH. Surgical techniques for total sacrectomy and spinopelvic reconstruction. Neurosurg Focus. 2003;15(2). doi:10.3171/ foc. 2003.15.2.5
17. Clarke MJ, Dasenbrock H, Bydon A, et al. Posterior-only approach for en bloc sacrectomy: Clinical outcomes in 36 consecutive patients. Neurosurgery. 2012;71(2):357-364. doi:10.1227/ NEU.0b013e 31825d01d4

18. Gunterberg B, Kewenter J, Petersén I, Stener B. Anorectal function after major resections of the sacrum with bilateral or unilateral sacrifice of sacral nerves. Br J Surg. 1976;63(7):546-554. doi:10.1002/bjs.1800630713

19. Wuisman P, Lieshout O, Sugihara S, Van Dijk M. Total sacretomy and reconstruction: Oncologic and functional outcome. Clin Orthop Relat Res. 2000;(381):192-203. doi:10.1097/00003086200012000-00023

20. Kim KR, Kim KH, Park JY, et al. Surgical strategy for sacral tumor resection. Yonsei Med J. 2021;62(1):59-67. doi:10.3349/ ymj.2021.62.1.59

21. Sabourin M, Biau D, Babinet A, Dumaine V, Tomeno B, Anract P. Surgical management of pelvic primary bone tumors involving the sacroiliac joint. Orthop Traumatol Surg Res. 2009;95(4):284-292. doi:10.1016/j. otsr.2009.04.008 


\title{
Резиме
}

\section{САКРЕКТОМИЈА СО ИЛИО-ЛУМБАЛНА СТАБИЛИЗАЦИЈА ЗА ХОНДРОСАРКОМ} СО НИЗОК МАЛИГНИТЕТ НА САКРУМ И ИЛИЈАЧНО КРИЛО. ПРИКАЗ НА СЛУЧАЈ НА ПРВАТА ХИРУРШКА ИНТЕРВЕНЦИЈА ИЗВЕДЕНА ВО РЕПУБЛИКА СЕВЕРНА МАКЕДОНИЈА

\author{
Илир Хасани ${ }^{1}$, Даница Поповска², Резеарт Далипи ${ }^{2}$, \\ Теодора Тодорова ${ }^{2}$, Ќмал Рушити $^{3}$ Никола Граматниковски ${ }^{4}$ \\ ${ }^{1}$ Универзитетска клиника за трауматологија - Скопје, Република Северна Македонија \\ 2 Универзитетска клиника за ортопедски болести - Скопје, Република Северна Македонија \\ ${ }^{3}$ Универзитетска клиника за дигестивна хирургија - Скопје, Република Северна Македонија \\ 4 Универзитетска клиника за торакална и васкуларна хирургија - Скопје, Република Северна \\ Македонија
}

Хондросаркомите со низок малигнитет се примарни малигни коскени тумори, кои се отпорни на хемотерапија и радиотерапија и поради тоа се лекуваат хируршки. Кај хондросаркомите на сакрумот, поради положбата во карлицата, зафатеноста на околните анатомски структури и големите димензии што ги постигнува туморот додека да биде откриен, хируршката ресекција е технички тешко изводлива, а ризикот од компликации е голем. Во овој труд претставуваме воведување нова хируршка техника, која за првпат се изведува во земјава: сакректомија со илиолумбална стабилизација, која беше изведена кај 67-годишен пациент со хондросарком со низок малигнитет на сакрумот со зафаќање на сакроилијачниот зглоб. Процедурата беше изведена преку комбиниран предно-заден пристап во две фази. За обезбедување на спинопелвичен континуитет и стабилност беше спроведена илиолумбална фиксација и премостување со титаниумски кафез со коскен графт. Сакректомијата е сложена процедура за која е потребно детално предоперативно планирање и мултидисциплинарен пристап, како и големо хируршко искуство.

Клучни зборови: хондросарком, сакректомија, илио-лумбална стабилизација 